\title{
Tinjauan yuridis pelaksanaan informed consent pemasangan AKDR pada akseptor KB
}

\author{
Dita Kristiana* \\ Prodi DIII Kebidanan Fakultas IImu Kesehatan Universitas ‘Aisyiyah Yogyakarta-Indonesia
}

\begin{abstract}
The regulation of health ministry number 1464 in 2010 about the permit and conduct of midwifery practice declares that in conducting the practice of midwifery, it is mandatory for a midwife to give the patient information about the service needed, ask for permission related to the planned interventions and make notes., The study aims to investigate the regulation of intrauterine device (IUD) informed consent administration, the reason of informed consent implementation and the implementation of intrauterine device informed consent administration at primary health centre of Yogyakarta., Juridical sociological method was used in the study, The study result shows that juridical review of the implementation of intrauterine device (IUD) informed consent is available atthe regulation of health ministry. In conclusion, all of the implementations of informed consent of intrauterine device administration are legal.
\end{abstract}

\section{Keywords: informed; consent; contraception}

\begin{abstract}
Abstrak
Peraturan Menteri Kesehatan No 28 tahun 2017 tentang Izin dan Penyelenggaraan Praktik Bidan menyatakan bahwa dalam melaksanakan praktik/kerja, bidan berkewajiban untuk memberikan in formasi tentang pelayanan yang dibutuhkan, meminta persetujuan tindakan yang akan dilakukan, melakukan pencatatan. Penelitian ini merupakan penelitian kualitatif bertujuan untuk mengetahui pengaturan informed consent pemasangan alat kontrasepsi dalam rahim, alas an dibutuhkannya informed consent dan pelaksanaan informed consent pemasangan alat kontrasepsi dalam rahim di Puskesmas Kota Yogyakarta. Metode penelitian yuridis sosiologis Hasil penelitian menunjukkan bahwa tinjauan yuridis pelaksanaan informed consent pemasangan AKDR terdapat pada Undang-undang dan Permenkes. Dari 13 responden di Puskesmas Jetis dan Tegalrejo, 12 informed consent sah, dan 1 tidak karena tidak ada tanda tangan bidan, pasien, maupun suami. Pengaturan informed consent pemasangan AKDR terdapat pada Undang-undang dan Permenkes.
\end{abstract}

Kata Kunci: informed; consent; kontrasepsi

* Corresponding Author: Dita Kristiana (sitakristiana@gmail.com) 


\section{Pendahuluan}

Tenaga kesehatan yang ingin melakukan tindakan lebih dahulu harus memberikan informasi mengenai tindakan apa yang akan dilakukan, apa manfaatnya, apa risikonya, alternative lain (jika ada), dan apa yang mungkin terjadi apabila tidak dilakukan. Evaluasi pelayanan KB AKDR hingga saat ini masih dirasa kurang berkualitas. Kebijakan program KB yang mengharuskan penyampaian konseling terhadap calon peserta KB belum dilaksanakan secara optimal oleh para pemberi pelayanan (provider), hal ini juga sebagai salah satu akibat dari "target oriented" yang lebih mementingkan kuantitas, akibatnya masih banyak dijumpai peserta KB yang belum benarbenar siap menjadi peserta akan memutuskan untuk berhenti menggunakan alat kontrasepsi bila pada saat memakai AKDR muncul efek samping atau masalah kesehatan yang mereka tidak pahami dengan baik.

Berdasarkan Peraturan Menteri Kesehatan Republik Indonesia Nomor 1464 tahun 2010 tentang Izin dan Penyelenggaraan Praktik Bidan Pasal 18 ayat (1) menyatakan bahwa dalam melaksanakan praktik/kerja, bidan berkewajiban untuk memberikan informasi tentang masalah kesehatan pasien dan pelayanan yang dibutuhkan, meminta persetujuan tindakan yang akan dilakukan, melakukan pencatatan asuhan kebidanan dan pelayanan lainnya secara sistematis.

Informasi tentang tindakan medis harus diberikan kepada pasien, baik diminta atau tidak oleh pasien tersebut. Kemudian berdasarkan informasi tersebut pasien akan memutuskan untuk menyetujui tindakan yang ditawarkan atau menolak persetujuan yang diberikan. Namun banyak masalah dan kendala timbul dalam praktek sehari-hari, seperti bahasa penyampaian informasi, batas banyaknya informasi yang harus/dapat diberikan, tidak seragamnya formulir tentang persetujuan yang didasarkan atas informasi atau penjelasan/persetujuan tindakan medik (informed consent), masalah ikut campurnya keluarga atau pihak ketiga dalam hal pemberian persetujuan, dan kesalahan yang dilakukan oleh tenaga kesehatan dalam pelaksanaan perjanjian tindakan kedokteran.

Pemberian informed consent hanya sebagian saja dari banyaknya akseptor KB yang ada dan ini membuktikan bahwa minimnya pelaksanaan informed consent pada akseptor KB. Data Pusat Kesehatan Masyarakat (Puskesmas) di Kota Yogyakarta Desember 2013 ada 18 dengan jenis rawat inap ada 2 yaitu Jetis dan Tegalrejo. Pada tahun 2016 
Januari sampai Agustus akseptor KB AKDR di Puskesmas Jetis ada 75 orang, sedangkan di Puskesmas Tegalrejo ada 90 orang. Selama ini jarang dilakukan evaluasi tentang penggunaan formulir-formulir yang disyaratkan salah satunya tentang implementasi penggunaan formulir informed consent.

Tujuan penelitian yaitu mengetahui pengaturan informed consent pemasangan AKDR, mengetahui alasan dibutuhkannya informed consent pemasangan AKDR, mengetahui pelaksanaan informed consent pemasangan AKDR di Puskesmas.

\section{Metode}

Variabel sebab kelengkapan informasi dan pengisian tanda tangan, variabel akibat yaitu informed consent AKDR.

Objek penelitian ini adalah seluruh informasi yang berkaitan dengan tinjauan yuridis pelaksanaan informed consent pemasangan alat kontrasepsi dalam rahim yaitu bidan, informed consent dan pasien.

Dalam penelitian ini data primer yaitu pelaksanaan pemberian informasi tentang alat kontrasepsi dalam rahim dan persetujuan tindakan pemasangan AKDR. Data sekundernya berupa lembar informed consent pemasangan AKDR.
Metode pengumpulan data melalui studi pustaka, observasi, wawancara. Penelitian dilakukan selama 4 bulan dengan jadwal setiap Rabu datang ke Puskesmas Tegalrejo karena jadwal pelayanan KB dan Kamis di Puskesmas Jetis pada jam kerja pagi yaitu jam 7.30-14.30 WIB. Observasi dilakukan dengan pengamatan pemberian informasi yang dilakukan oleh bidan kepada pasien tentang pemasangan alat kontrasepsi dalam rahim menggunakan lembar observasi dan pengamatan lembar persetujuan tindakan medik pemasangan AKDR yang dilakukan oleh bidan kepada 5 akseptor KB AKDR tahun 2016. Analisis data yang digunakan dengan analisis data kualitatif dan kuantitatif. Analisis kualitatif digunakan untuk memperoleh data terkait tinjauan yuridis pelaksanaan informed consent pemasangan AKDR meliputi informasi yang diberikan bidan kepada pasien dan lembar informed consent di Puskesmas Jetis dan Tegalrejo

\section{Hasil dan Pembahasan}

Pengaturan Informed Consent Pemasangan AKDR

1. Undang-undang Nomor 29 tahun 2004 tentang Praktik Kedokteran Paragraf 2 Persetujuan Tindakan Kedokteran atau 
Kedokteran Gigi Pasal 52. Sesuai dengan pasal tersebut, hak pasien di Puskesmas Tegalrejo dan Jetis untuk mendapatkan penjelasan secara lengkap tentang tindakan medis sudah terpenuhi.

2. Undang-undang No 36 Tahun 2009 tentang Kesehatan Pasal 56 ayat (1). Berdasarkan observasi, semua responden dalam penelitian ini menerima seluruh tindakan pemasangan alat kontrasepsi dalam rahim yang akan diberikan kepadanya setelah menerima dan memahami informasi mengenai tindakan tersebut secara lengkap.

3. Undang-Undang No 44 Tahun 2009 tentang Rumah Sakit Pasal 32. Pasien di Puskesmas Jetis dan Tegalrejo sudah terpenuhi haknya dengan memperoleh layanan kesehatan yang bermutu sesuai dengan standar profesi bidan. Pasien telah memperoleh informasi mengenai tata cara pemasangan alat kontrasepsi dalam rahim, tujuan, risiko, komplikasi yang mungkin terjadi serta perkiraan biaya.

4. Peraturan Menteri Kesehatan No 290 tahun 2008 tentang Persetujuan tindakan kedokteran pasal 2 ayat (2). Persetujuan tindakan pemasangan alat kontrasepsi dalam rahim diberikan secara tertulis. Pasal 3 ayat (3) persetujuan tertulis dibuat dalam bentuk pernyataan yang tertuang dalam formulir persetujuan tindakan Peraturan Menteri Kesehatan Republik Indonesia Nomor 1464 tahun 2010 BAB III Penyelenggaraan Praktik Pasal 13. Bidan di Puskesmas Jetis dan Tegalrejo menjalankan program Pemerintah dengan melakukan pelayanan kesehatan alat kontrasepsi dalam rahim. Sesuai dengan Pasal 18, bidan dalam melaksanakan praktik/kerja sudah memberikan informasi tentang masalah kesehatan pasien dan pelayanan yang dibutuhkan, meminta persetujuan tindakan yang akan dilakukan, namun belum 100\%. Pasal 21 ayat (3) Kepala Dinas Kesehatan Kota harus melaksanakan pembinaan dan pengawasan penyelenggaraan praktik bidan.

Alasan Dibutuhkannya Informed Consent Pemasangan AKDR

Terdapat pada Permenkes RI No. 1464 tahun 2010 tentang Izin dan Penyelenggaraan Praktik Bidan Pasal 18 dalam melaksanakan praktik/kerja bidan berkewajiban memberikan 
informasi tentang pelayanan yang dibutuhkan, meminta persetujuan tindakan yang akan dilakukan, melakukan pencatatan asuhan kebidanan dan pelayanan lainnya secara sistematis.

Penelitian dilakukan di Puskesmas Tegalrejo, Yogyakarta. Bidan di Puskesmas Tegalrejo ada 5 yaitu Bidan E, Yun, Yul, S, I. Bidan Yul mengatakan bahwa: "alasan dibutuhkannya informed consent yaitu keamanan bidan, ketika akan dilakukan tindakan ada bukti tertulis. Kalau ada sesuatu ada persetujuan, sesuai SOP Puskesmas Tegalrejo. Selama ini tidak pernah ada kasus. Penelitian juga dilakukan di Puskesmas Jetis Yogyakarta. Bidan di poliklinik KIA ada 4 orang dengan jenjang pendidikan diploma III Kebidanan yaitu Bidan J, N, S, A. Bidan J mengatakan bahwa: "alasan dibutuhkannya informed consent karena wajib, kebutuhan. Misal mau kb ulangan. Pasien tau tindakan yang akan diberikan oleh bidan. Kalau setuju ga ada masalah. Kalau ingin pil tapi dilayani suntik berarti ga sesuai. Harus sesuai persetujuan".

Wawancara juga dilakukan kepada pasien di Puskesmas Tegalrejo. Menurut Ibu A, pasien yang akan dipasang AKDR mengatakan bahwa: "alasan dibutuhkannya informed consent pemasangan alat kontrasepsi dalam rahim ya biar formulir Puskesmas Tegalrejo lengkap. Pasien Ibu L, mengatakan bahwa: "alasan dibutuhkannya informed consent, suami harus tahu tentang alat kontrasepsi dalam rahim yang dipasang kepada istrinya". Pasien Ibu D mengatakan bahwa: "alasan dibutuhkannya informed consent, saya mengisi dan tanda tanda tangan untuk data diri di formulir persetujuan tindakan". Pasien Ibu W mengatakan bahwa: "alasan dibutuhkannya informed consent saya tidak tahu, disuruh ngisi formulir ya ngisi".

Pasien Ibu A mengatakan bahwa: "alasan dibutuhkannya informed consent, kalau ada risiko tentang pemasangan alat kontrasepsi dalam rahim sudah disetujui oleh saya maupun suami". Pasien Ibu L mengatakan bahwa: alasan dibutuhkannya informed consent, saya dan suami kan dijelaskan tentang pemasangan alat kontrasepsi dalam Rahim. Itu biar tahu kesehatan". Pasien Ibu K mengatakan bahwa: "alasan dibutuhkannya informed consent untuk data di Puskesmas Jetis".

Berdasarkan penelitian, terdapat 5 pasien yang akan dipasang AKDR di Puskesmas Jetis Yogyakarta. Bidan belum tanda tangan pada formulir persetujuan tindakan. Ada 4 klien tanda tangan pada formulir persetujuan tindakan dan 1 klien tidak tanda tangan. Ada 2 
suami tanda tangan pada formulir persetujuan tindakan, 3 suami tidak tanda tangan pada lembar persetujuan tindakan karena tidak ikut ke Puskesmas. Semua pasien diatas diberikan informasi tentang AKDR oleh bidan.

Berdasarkan penelitian, terdapat 8 pasien yang akan dipasang AKDR di Puskesmas Tegalrejo Yogyakarta tahun 2016. Bidan tanda tangan pada 3 formulir persetujuan tindakan dan 5 formulir belum ditandatangan. Klien $100 \%$ sudah tandatangan pada formulir persetujuan tindakan. Ada 1 saudara dan 1 orang tua tanda tangan pada kolom suami dan suami tidak ikut. Ada 2 suami setuju tetapi tidak tanda tangan. Ada 2 suami tanda tangan pada formulir persetujuan tindakan. Semua pasien di atas diberikan informasi tentang AKDR. Sesuai Pemenkes 290 tahun 2008 tentang Tindakan Persetujuan Kedokteran Bab III yang berhak memberikan persetujuan pasal 13 ayat (1) persetujuan diberikan oleh pasien yang kompeten atau keluarga terdekat, jadi 12 formulir persetujuan tindakan di Puskesmas Tegalrejo sah dan 1 tidak sah.

Pengaturan informed consent pemasangan AKDR terdapat pada Undng-undang dan Permenkes bahwa pasien berhak menolak atau menerima seluruh tindakan pemasangan alat kontrasepsi dalam rahim yang akan diberikan kepadanya setelah menerima dan memahami informasi mengenai tindakan tersebut secara lengkap meliputi tata cara pemasangan alat kontrasepsi dalam rahim, tujuan, risiko, komplikasi yang mungkin terjadi serta perkiraan biaya dibuktikan dengan persetujuan tertulis dalam bentuk pernyataan yang tertuang dalam formulir persetujuan tindakan.

Alasan dibutuhkannya informed consent pemasangan alat kontrasepsi dalam rahim merupakan kewajiban bidan sesuai Permenkes RI Nomor 1464 tahun 2010 tentang Izin dan Penyelenggaraan Praktik Bidan Pasal 18.

Pelaksanaan informed consent pemasangan alat kontrasepsi dalam rahim di Puskesmas Jetis dan Tegalrejo, pemberian informasi sudah dilakukan, dari 13 responden di Puskesmas Jetis dan Tegalrejo, 12 informed consent sah, dan 1 tidak karena tidak ada tanda tangan bidan, pasien, maupun suami.

\section{Kesimpulan}

Berdasarkan kesimpulan dalam penelitian ini, maka dapat disarankan beberapa hal sebagai berikut: Meningkatkan pembinaan dan pengawasan penyelenggaraan praktik bidan khususnya terkait informed consent. Bidan memberikan in- 
formed consent dan melakukan pengisian formulir secara lengkap.

\section{Daftar Pustaka}

Arsyaningsih, N., Suhartono, S., \& Suherni, T. (2013). Analisis Faktor-Faktor yang Mempengaruhi Kualitas Pelayanan Konseling Keluarga Berencana Alat Kontrasepsi Dalam Rahim oleh Bidan di Wilayah Kerja Puskesmas Wiradesa Kabupaten Pekalongan Tahun 2013. Jurnal Kebidanan, 3(6), 17-29.

Bustami. Penjaminan Mutu Pelayanan Kesehatan dan Akseptabilitasny. Penerbit Erlangga. Jakarta. 2011

Depkes. RI. Profil Kesehatan Provinsi Jawa Tengah tahun 2008. 12 April 2012. diambil dari: http:// profil-kesehatan-Jateng2008-de pkes.com

Handayani, S. Pelayanan Keluarga Be rencana (KB). EGC. Jakarta. 2010

Kitab Undang-Undang Hukum Perdata. (1847)

Manuaba, IBG. Ilmu Kebidanan Penya kit Kandungan dan Keluarga Berencana untuk Pendidikan Bidan. EGC. Jakarta. 2010

Peraturan Menteri Kesehatan Republik Indonesia Nomor 290/Menkes/Per/III/2008 tentang Persetujuan Tindakan Kedokteran

Peraturan Menteri Kesehatan Republik Indonesia Nomor 28 Tahun 2017 tentang Izin dan Penyelenggaraan Praktik Bidan

Rahmayani, D. (2013). Karakteristik Akseptor Non AKDR tentang Kontrasepsi AKDR. Dinamika Kesehatan. Vol.12
Rozana, E. (2010). Evaluasi Pelaksanaan Informed Consent pada Akseptor KB di RSU PKU Muhammadiyah Yogyakarta

Puspitasari, Diah. Policy Brief Kajian Implementasi Kebijakan Penggu- naan Kontrasepsi. 20 Juni 2012. diambil dari: http://www. bkkbn. go.id/litbang/pusna/data/PB-Diah edit.pdf

Sastroasmoro,S. (2010). Mengurai dan Merajut Desertasi dan Tesis Bidang Kedokteran dan Kesehatan.Jakarta: Ikatan Dokter Anak Indonesia

Sunarto, Kependudukan, BKKBN Provinsi Jawa Tengah. Semarang. 2010

Suratman, P. (2012). Metode Penelitian Hukum. Bandung: Alfabeta

Susanti, N. (2010). Statistika Deskriptif dan Induktif. Yogyakarta: Graha Ilmu

Undang-Undang Republik Indonesia Nomor 29 Tahun 2004 tentang Praktik Kedokteran

Undang-Undang Republik Indonesia Nomor 36 Tahun 2014 tentang Tenaga Kesehatan

Undang-Undang Republik Indonesia Nomor 36 Tahun 2009 tentang Kesehatan

Undang-Undang Republik Indonesia Nomor 44 Tahun 2009 tentang Rumah Sakit

Yuhedi, L. (2013). Buku Ajar Kependudukan dan Pelayanan KB. Jakarta: Buku Kedokteran EGC 
